\title{
Tea consumption and the risk of ovarian cancer: A meta-analysis of epidemiological studies
}

\author{
Xin Zhan ${ }^{1, *}$, Jie Wang ${ }^{2, *}$, Shufen Pan ${ }^{3}$, Caijuan Lu ${ }^{1}$ \\ ${ }^{1}$ Obstetrics and Gynecology Department, Hangzhou First People's Hospital, Hangzhou, Zhejiang 310006, PR China \\ ${ }^{2}$ Obstetrics and Gynecology Department, The First Affiliated Hospital of Zhejiang Chinese Medical University Zhejiang \\ Provincial Hospital of TCM, Hangzhou, Zhejiang 310016, PR China \\ ${ }^{3}$ Department of Obstetrics and Gynecology, Central Hospital of Wenzhou, Luchengqu, Wenzhou, Zhejiang 325000, PR China \\ *These authors contributed equally to this work
}

Correspondence to: Caijuan Lu, email: goaltarget@163.com

Keywords: ovarian cancer, tea, meta-analysis

Received: November 08, $2016 \quad$ Accepted: March 27, $2017 \quad$ Published: April 06, 2017

Copyright: Zhan et al. This is an open-access article distributed under the terms of the Creative Commons Attribution License (CC-BY), which permits unrestricted use, distribution, and reproduction in any medium, provided the original author and source are credited.

\section{ABSTRACT}

A large number of epidemiological studies have provided conflicting results about the relationship between tea consumption and ovarian cancer. This study aimed to clarify the association between tea consumption and ovarian cancer. $A$ literature search of the MEDICINE, Scopus, PubMed, and Web of Science databases was performed in April 2016. A total of 18 (11 case-control and 7 cohort) studies, representing data for 701,857 female subjects including 8,683 ovarian cancer cases, were included in the meta-analysis. A random-effects meta-analysis was used to compute the pooled relative risks (RR), meta regression, and publication bias, and heterogeneity analyses were performed for the included trials. We found that tea consumption had a significant protective effect against ovarian cancer (relative risk $[R R]=0.86 ; 95 \%$ confidence interval $[\mathrm{CI}]: 0.76,0.96)$. The relationship was confirmed particularly after adjusting for family history of cancer ( $R R=0.85 ; 95 \%$ CI: $0.72,0.97)$, menopause status $(R R=0.85 ; 95 \% C I: 0.72,0.98)$, education $(R R=0.82$; 95\% CI: 0.68, 0.96), BMI (RR $=0.85 ; 95 \%$ CI: 0.70, 1.00), smoking ( $R R=0.83 ; 95 \%$ CI: $0.72,0.93)$ and Jadad score of 3 (RR $=0.76 ; 95 \% \mathrm{CI}: 0.56,0.95)$ and 5 (RR = 0.74; 95\% CI: 0.59, 0.89). The Begg's and Egger's tests (all $P>0.01$ ) showed no evidence of publication bias. In conclusion, our meta-analysis showed an inverse association between tea consumption and ovarian cancer risk. High quality cohort-clinical trials should be conducted on different tea types and their relationship with ovarian cancer.

\section{INTRODUCTION}

Ovarian cancer has the sixth-highest prevalence among cancers worldwide and is the primary cause of death due to gynecologic malignancy $[1,2]$. Because most patients with cancer have been diagnosed at an advanced stage, its mortality rate is high and $<50 \%$ of patients live beyond 5 years after diagnosis [3]. The incidence of ovarian cancer widely differs among regions, races, and ethnicities: The incidence in the Asian population is much lower than that in the European population, indicating that lifestyle and eating habits may play an important role in the pathogenesis of ovarian cancer [4]. The influence of lifestyle on cancer has been reported in many studies. Changes in lifestyle factors, including diet, can prevent several types of cancers such as colorectal cancer, bladder cancer, ovarian cancer, and liver cancer [5-7]. Many in vitro and animal experiments have shown that tea contains a variety of complexes, especially polyphenols (green tea), which play a significant role in inhibiting the growth of cancer cells $[8,9]$.

Several epidemiological studies including case-control and cohort studies have investigated the association between tea consumption and ovarian cancer risk; however, their results were inconsistent. In 2015, Zhang et al. [10] performed a meta-analysis of observational studies that investigated the association between green tea intake and ovarian cancer risk and reported that high tea consumption had no significant effect on the risk of many cancers, including gastric, rectal, 
lung, colon, pancreatic, liver, breast, ovarian, prostate, and bladder cancers. However, their meta-analysis only included 6 observational studies, and their methodology was not comprehensive, as it did not include sub-group analyses according to the geographic location, adjustment for factors, Jadad scores from the literature, sensitivity analysis, and meta-regression analysis. Therefore, they were unable to identify potential sources of heterogeneity. In addition, no statistical significance was reported between tea consumption and ovarian cancer risk in 2 other meta-analyses $[11,12]$. However, in another metaanalysis, tea consumption was found to be inversely, but not significantly, associated with ovarian cancer risk [13].

In order to clarify whether tea consumption is associated with ovarian cancer risk, this study aimed to perform a comprehensive meta-analysis of 18 epidemiological studies.

\section{RESULTS}

\section{Literature search and study characteristics}

Figure 1 illustrates the search process and the final selection of relevant studies. A total of 87 records were identified through database searching, and 30 additional records were identified through examination of reference lists. On the basis of the titles and abstracts, we identified 33 full-text articles. After further evaluation, 15 studies were excluded due to the lack of available data, duplicated reports, and Jadad score $<3$. Finally, 18 [12-29] eligible studies published between 1987 and 2015 were identified, including 11 case-control studies $[14,15,17,20,22-26$, $28,29]$ and 7 cohort studies [12, 13, 16, 18, 19, 21, 27] (Figure 2). Of the 18 included studies, 8 were conducted in USA $[16,17,19,20,24,26,27,29] ; 2$ in Australia $[15,22] ; 2$ in Italy $[25,28]$; and 1 in Netherlands, Europe, Denmark, Canada, Sweden, and China [12-14, 18, 21, 23]. A total of 701,857 female subjects, including 8,683 ovarian cancer cases, were included. Most studies matched or adjusted for some potential confounders, including age, education, total energy intake, and use of oral contraceptives (OCPs). The Jadad scores for the included studies ranged from 3-5. Table 1 summarizes the quality scores of the cohort studies and case-control studies.

\section{Main analysis}

In a stratified analysis, we found a statistically significant inverse association between tea consumption and ovarian cancer risk in studies that did not adjust for family history of cancer $(\mathrm{RR}=0.85,95 \%$ CI: $0.72,0.97)$, education $(\mathrm{RR}=0.82,95 \% \mathrm{CI}: 0.68$, $0.96)$, oral contraceptive (OCP) use $(\mathrm{RR}=0.81,95 \%$ CI: 0.71, 0.91), BMI (RR =0.85, 95\% CI: 0.70, 1.00), smoking $(\mathrm{RR}=0.83,95 \% \mathrm{CI}: 0.72,0.93)$, and menopause status $(\mathrm{RR}=0.85,95 \% \mathrm{CI}: 0.72,0.98)$, in studies with
Jadad scores of $3(\mathrm{RR}=0.76,95 \% \mathrm{CI}: 0.56,0.95)$ and $5(\mathrm{RR}=0.74,95 \% \mathrm{CI}: 0.59,0.89)$, in cohort study $(\mathrm{RR}=0.80,95 \% \mathrm{CI}: 0.62,0.97)$, in Oceania $(\mathrm{RR}=0.77$, 95\% CI: $0.55,0.99)$, and in America $(\mathrm{RR}=0.84,95 \%$ CI: $0.71,0.98)$. Furthermore, statistically significantly inverse associations were identified in studies from the United States $(\mathrm{RR}=0.83,95 \%$ CI: 0.69, 0.97) and Sweden $(\mathrm{RR}=0.54,95 \% \mathrm{CI}: 0.31,0.91)($ Table 2). Figure 3 presents the publication dates of the studies. As can be seen from the figure, the results showed that omission of any study could not altered the observed effect, excluding any study, the rest studies' combined effects still fall within the total combined effect. The results are consistent, and it provides stronger evidence of an effect and of generalizability.

\section{Meta-regression analysis and publication bias}

We performed a meta-regression analysis to test the study design and geographic area. We found that study design (47.90\%) and geographical region (44.60\%) was statistically significant in the multivariate model (Figure 4A, 4B). Interpretation of Figures 5 and 6 revealed no support for publication bias. Furthermore, Begg's and Egger's tests (all $P>0.01$ ) indicated no evidence of publication bias among studies (Figures 5 and 6).

\section{DISCUSSION}

This meta-analysis showed that tea consumption significantly reduces the risk of ovarian cancer. Our metaregression analysis revealed that the study design may be the source of heterogeneity between studies (47.90\%), and geographical region was associated with a $44.60 \%$ heterogeneity reduction across the studies. In addition, our results were not altered by the control source and most confounder adjustments such as education, OCP use, BMI, and smoking in the subgroup analyses. However, the association was substantially altered by a few confounder adjustments, i.e., family history of cancer, menopause status, and Jadad score.

Stratification by country showed that tea consumption decreased the risk of ovarian cancer only in studies conducted in the United States and Sweden. Geographical differences may be a result of various factors such as the differences in genetic susceptibility, culture, and lifestyles. Moreover, the types of tea and frequency of tea consumption differ among different areas. Our sensitivity analysis indicated that omission of any study did not significantly alter the magnitude of the observed effect, indicating the stability of our findings. Moreover, the Begg's and Egger's tests showed that no publication bias existed.

Many cell in vitro experiments and animal experiments have shown that tea has significant anticancer effects [30-32]. To a certain extent, a meta-analysis 
can compensate for the limitations of a single study to resolve the contradiction between the conclusions of the study. Prior meta-analyses also found that tea tends to reduce the incidence of ovarian cancer, but the results were not statistically significant [10-13]; these metaanalyses, selected from the English literature, studied the consumption of different types of tea including green tea and black tea, and the target population was mostly the Caucasian population, which could lead to some bias.

Tea is a relatively inexpensive and safe drink and prevents ovarian cancer by a variety of mechanisms. Tea polyphenols are useful components of the tea extract that can down-regulate the expression of a variety of tumor genes, induce tumor cell apoptosis, block tumor cell cycle, up-regulate the body metabolism, and remove excess free radicals, ultimately playing a role in the prevention and inhibition of tumors [33-36]. Some polyphenols can induce tumor cell apoptosis and inhibit tumor angiogenesis. The consumption of black tea, in particular, which is rich in polyphenols, has been found to significantly reduce the risk of ovarian cancer [37]. However, evidence for the efficacy of black tea for prevention of cancer is not conclusive [12]. On the other hand, green tea contains a variety of phenolic compounds that have a strong antioxidant activity, and its anti-cancer effect is much stronger than that of black tea [13]. One of the main components of green tea is catechol (epigallocatechin gallate), which has remarkable antioxidant activity and can effectively inhibit the growth and evolution of cancer cells [38]. In the Asian population, especially in the Chinese population, the amount of green tea consumed is much higher than that of black tea, but data on this issue are scarce. The effect of tea may also differ due to the difference in genetic heterogeneity and lifestyle among populations. In addition, the various ingredients in tea can have different anticancer activities and effects on different types and subtypes of ovarian cancer [20], which have not yet been explored.

The strength of the present meta-analysis is its large sample size $(701,857$ female subjects and 8,683 ovarian cancer cases) and no significant evidence of publication bias. Furthermore, our findings were stable and robust. However, there were several limitations that should be noted. First, as a meta-analysis of observational data, the possibility of recall and selection biases cannot be ruled out. Only 5 cohort studies investigated the association between tea intake and ovarian cancer risk, which was a rather small number to draw concrete conclusions from.

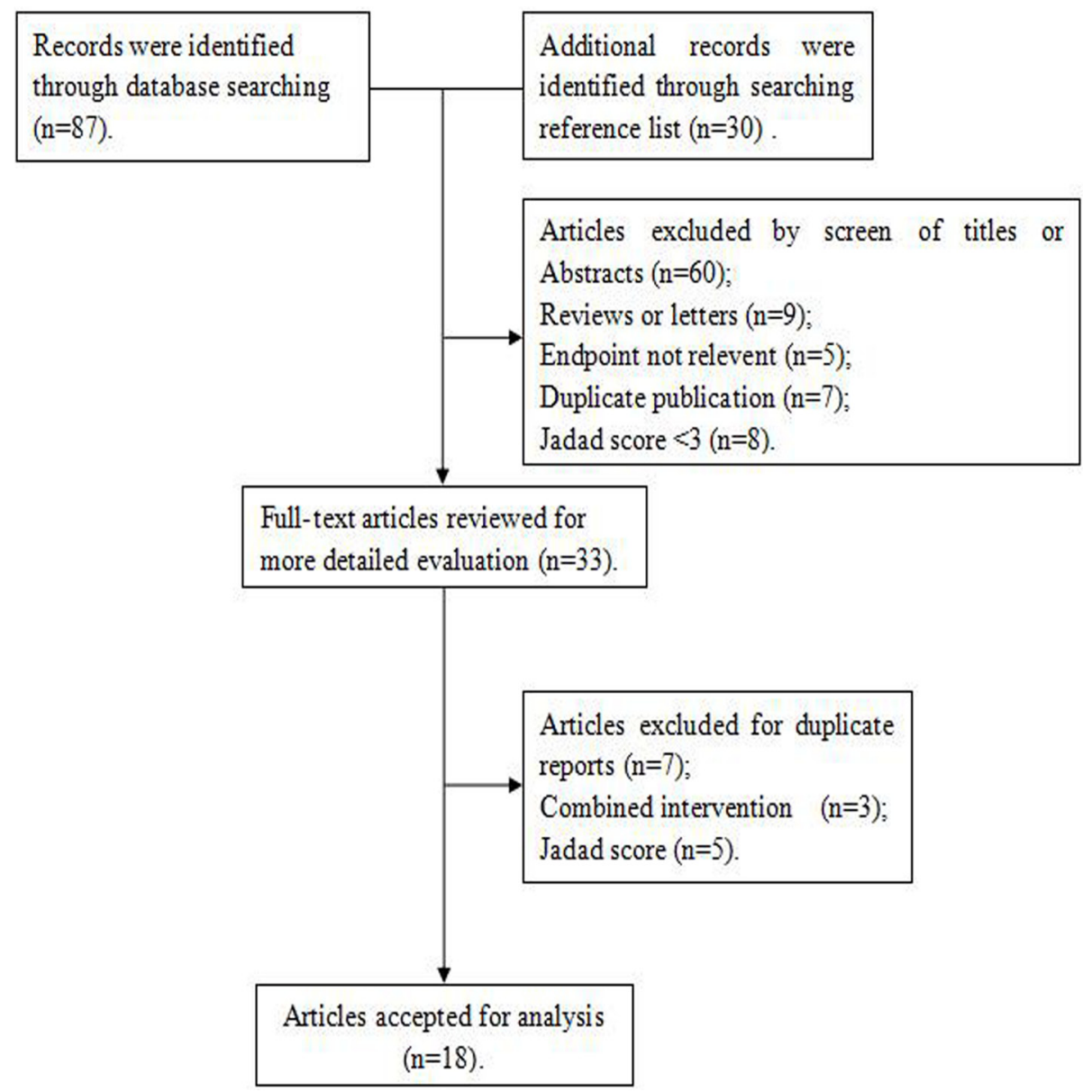

Figure 1: Search strategy and selection of studies. 
Table 1: Characteristics of the studies included in the meta-analysis

\begin{tabular}{|c|c|c|c|c|c|c|c|c|}
\hline Study & Year & Country & Study period & No. of cases/size & Exposure range & $\begin{array}{l}\text { Adjusted RR } \\
(95 \% \mathrm{CI})\end{array}$ & Adjustment for covariates & Jadad score \\
\hline $\begin{array}{l}\text { Gosvig } \mathrm{CF} \\
\text { et al. }\end{array}$ & 2015 & Denmark & 1995-1999 & $382 / 911$ & $\geq 4$ cups $/$ day; 0 & $0.81(0.48-1.42)$ & $\begin{array}{l}\text { Pregnancy (ever/never), number of pregnancies (linear), } \\
\text { oral contraceptive use (ever/never), duration of OCP } \\
\text { use (linear) }\end{array}$ & 4 \\
\hline $\begin{array}{l}\text { Braem MG } \\
\text { et al. }\end{array}$ & 2012 & Europe & $1992-2000$ & $241 / 330,849$ & highest; lowest & $1.07(0.78,1.46)$ & $\begin{array}{l}\text { OCP, BMI, smoking status, alcohol consumption, total } \\
\text { energy intake, duration of breastfeeding, menopausal } \\
\text { status, height, and educational level. }\end{array}$ & 4 \\
\hline $\begin{array}{l}\text { Nagle CM } \\
\text { et al. }\end{array}$ & 2010 & Australia & $2002-2005$ & $1,271 / 1,198$ & $\begin{array}{l}\geq 4 \text { cups } / \text { day; } \\
\text { Never }\end{array}$ & $0.71(0.52-0.97)$ & $\begin{array}{l}\text { Age, education, parity, hormonal contraceptive use, } \\
\text { smoking status (current, ex, or non), fruit consumption, } \\
\text { vegetable consumption, coffee consumption, } \\
\text { consumption of other types of tea }\end{array}$ & 3 \\
\hline $\begin{array}{l}\text { Tworoger } \\
\text { SS et al. }\end{array}$ & 2008 & USA & 1976-2004 & $507 / 80,253$ & $\begin{array}{l}\geq 2 \operatorname{cups} / \mathrm{d} ; \leq 1 \\
\operatorname{cup} / \mathrm{wk}\end{array}$ & $0.96(0.70,1.30)$ & $\begin{array}{l}\text { Age, parity, OCP use, postmenopausal hormone use, } \\
\text { tubal ligation, BMI }\end{array}$ & 4 \\
\hline $\begin{array}{l}\text { Song } \quad \text { YJ } \\
\text { et al. }\end{array}$ & 2008 & USA & $2002-2005$ & $781 / 1,263$ & $\geq 1 \mathrm{cup} / \mathrm{d} ;$ Non & $0.92(0.63-1.33)$ & $\begin{array}{l}\text { Age, county, year of diagnosis/reference date, race/ } \\
\text { ethnicity, number of full-term pregnancies, duration } \\
\text { of hormonal contraception, education, BMI, smoking, } \\
\text { tubal ligation/hysterectomy, family history of breast/ } \\
\text { ovarian cancer }\end{array}$ & 3 \\
\hline $\begin{array}{l}\text { Steevens J } \\
\text { et al. }\end{array}$ & 2007 & Netherlands & $1986-2000$ & $280 / 62,573$ & $\begin{array}{l}\geq 5 \operatorname{cups} / \mathrm{d} ; 1-3 \\
\operatorname{cups} / \mathrm{d}\end{array}$ & $0.65(0.41,1.03)$ & Age, use of oral contraceptives (ever/never) & 4 \\
\hline $\begin{array}{l}\text { Silvera SA } \\
\text { et al. }\end{array}$ & 2007 & Canada & $1980-1985$ & $264 / 49,613$ & $\begin{array}{l}\geq 4 \operatorname{cups} / \mathrm{d} ; 0 \\
\quad \text { cups } / \mathrm{d}\end{array}$ & $1.07(0.64,1.79)$ & $\begin{array}{l}\text { Age, smoking history, pack-years of smoking, alcohol } \\
\text { intake, education, BMI, parity, participation in vigorous } \\
\text { physical activity, menopausal status, OCP use, energy } \\
\text { intake, lactose intake, study center, randomization } \\
\text { group }\end{array}$ & 3 \\
\hline $\begin{array}{l}\text { Baker JA } \\
\text { et al.. }\end{array}$ & 2007 & USA & 1982-1998 & $414 / 828$ & $\geq 2$ cups $/$ day; 0 & $0.70(0.51-0.97)$ & Age, residence, and year of participation & 5 \\
\hline $\begin{array}{l}\text { Gates MA } \\
\text { et al. }\end{array}$ & 2007 & USA & 1984-2002 & $577 / 66,940$ & $\begin{array}{l}>2 / \text { day; } \leq 1 / \text { week } \\
\quad \text { (servings) }\end{array}$ & $0.63(0.40,0.99)$ & $\begin{array}{l}\text { Age, duration of OCP use, parity, history of tubal } \\
\text { ligation, smoking status, history of postmenopausal } \\
\text { hormone use, physical activity, lactose intake, total } \\
\text { energy intake }\end{array}$ & 5 \\
\hline $\begin{array}{l}\text { Larsson } \\
\text { et al. }\end{array}$ & 2005 & Sweden & 1987-2004 & $301 / 61,057$ & $\begin{array}{l}\geq 2 \text { cups } / \text { day; } 0 \\
\text { cups } / \mathrm{d}\end{array}$ & $0.54(0.31-0.91)$ & $\begin{array}{l}\text { Age (in months); BMI; education; parity; OCP use; } \\
\text { intake of total energy; consumption of fruit, vegetables, } \\
\text { milk, liquor, beer, wine, and coffee }\end{array}$ & 5 \\
\hline Jordan et al. & 2004 & Australia & $1990-1993$ & $696 / 786$ & $\begin{array}{l}\geq 4 \operatorname{cups} / \text { day; } 0 \\
\text { cups } / \mathrm{d}\end{array}$ & $1.10(0.76-1.61)$ & $\begin{array}{l}\text { Age, age squared, BMI, duration of OCP, parity, } \\
\text { smoking, alcohol, education, energy intake. }\end{array}$ & 4 \\
\hline $\begin{array}{l}\text { Yen } \quad \text { ML } \\
\text { et al }\end{array}$ & 2003 & Taiwan,China & $1993-1998$ & $86 / 369$ & Yes; No & $0.79(0.47-1.32)$ & $\begin{array}{l}\text { Age, income during marriage, and education, number } \\
\text { of live births was made on the analysis of age at } \\
\text { first pregnancy, number of incomplete pregnancies, } \\
\text { breastfeeding, OCP use, intrauterine device use }\end{array}$ & 4 \\
\hline $\begin{array}{l}\text { Goodman } \\
\text { et al. }\end{array}$ & 2003 & USA & 1993-1999 & $164 / 194$ & $\begin{array}{l}\geq 1 \text { cups } / \text { week } ; \leq \\
1 \text { cups/week }\end{array}$ & $0.99(0.65-1.51)$ & Age, ethnicity, OCP, tubal ligation & 4 \\
\hline Tavani et al. & 2001 & Italy & 1992-1999 & $1,031 / 2,411$ & $\begin{array}{l}\geq 1 \mathrm{cups} / \mathrm{month} \\
\text { None }\end{array}$ & $0.90(0.75-1.08)$ & $\begin{array}{l}\text { Study center, year of interview, age, education, parity, } \\
\text { age at menopause, OCP, family history of ovarian/ } \\
\text { breast cancer, BMI, total energy intake }\end{array}$ & 5 \\
\hline Kuper et al. & 2000 & USA & 1992-1997 & $549 / 516$ & $\geq$ weekly; Rarely & $1.06(0.83-1.36)$ & Age, center activity & 4 \\
\hline Zheng et al. & 1996 & USA & 1986-1993 & $107 / 35,369$ & $\begin{array}{l}\geq 2 \text { cups/day; } \\
\text { Never or monthly }\end{array}$ & $0.98(0.50-1.90)$ & $\begin{array}{l}\text { Age at menarche, age at menopause, age at first } \\
\text { pregnancy, age, education, smoking status, pack-years } \\
\text { smoking, physical activity, fruit/vegetable intake, waist/ } \\
\text { hip ratio, family history of cancer }\end{array}$ & 5 \\
\hline $\begin{array}{l}\text { La Vechia } \\
\text { et al. }\end{array}$ & 1992 & Italy & $1983-1990$ & $742 / 6,147$ & $\begin{array}{l}\geq 1 \text { cups/day; } \\
\quad \text { None }\end{array}$ & $1.2(1.0-1.4)$ & $\begin{array}{l}\text { Age, area of residence, education, smoking, coffee } \\
\text { consumption }\end{array}$ & 4 \\
\hline Miller et al. & 1987 & USA & 1976-1983 & $290 / 580$ & $\geq 5$ cups $/$ day; 0 & $0.50(0.2-1.0)$ & $\begin{array}{l}\text { Age, race, religion, smoking, alcohol, OCP use, } \\
\text { estrogen use, BMI, age at menarche, age at first } \\
\text { pregnancy, parity, age at menopause, type of } \\
\text { menopause, years of education, geographical location } \\
\text { of hospital, year of interview, no. of lifetime non- } \\
\text { obstetric hospital admissions. }\end{array}$ & 3 \\
\hline
\end{tabular}

USA: the United States of America, BMI: body mass index, CI: confidence interval, RR: relative risk, OCP: oral contraceptive pill.

Compared with case-control studies, cohort studies are less susceptible to bias (e.g., recall bias and selection bias) due to their nature. Therefore, more prospective cohort studies are required on this issue in the future. Second, we did not search for unpublished studies, and only published studies were included in our meta-analysis. Third, publication bias may have occurred, although no publication bias was indicated from both visualization of the funnel plot, the Begg's test and the Egger's test. Fourth, no subanalyses on the histological types of ovarian cancer were performed. Given the heterogeneity of ovarian cancer, this is an important limitation of the study. Fifth, most of the included studies originated from the United States and Europe. Finally, although different types of tea (red, green, and black tea) may have different effects on the risk of ovarian cancer, we did not perform a 
Table 2: Stratified analysis of ovarian cancer in relation to tea consumption according to study characteristics

\begin{tabular}{|c|c|c|c|c|}
\hline Group & No. of studies & $\operatorname{RR}(95 \% \mathrm{CI})$ & $\boldsymbol{P}_{\text {heterogeneity }}$ & $I^{2}(\%)$ \\
\hline \multicolumn{5}{|l|}{ Adjustment } \\
\hline \multicolumn{5}{|c|}{ Family history of cancer } \\
\hline Yes & 3 & $0.91(0.76,1.05)$ & 0.973 & 0 \\
\hline No & 15 & $0.85(0.72,0.97)$ & 0.003 & 57 \\
\hline \multicolumn{5}{|l|}{ Menopause } \\
\hline Yes & 5 & $0.89(0.71,1.07)$ & 0.269 & 22.8 \\
\hline No & 13 & $0.85(0.72,0.98)$ & 0.006 & 56.5 \\
\hline \multicolumn{5}{|l|}{ Education } \\
\hline Yes & 11 & $0.88(0.74,1.03)$ & 0.010 & 56.9 \\
\hline No & 7 & $0.82(0.68,0.96)$ & 0.212 & 28.4 \\
\hline \multicolumn{5}{|l|}{ OCP use } \\
\hline Yes & 14 & $0.81(0.71,0.91)$ & 0.218 & 21.7 \\
\hline No & 4 & $0.99(0.72,1.26)$ & 0.014 & 71.6 \\
\hline \multicolumn{5}{|l|}{ BMI } \\
\hline Yes & 8 & $0.87(0.72,1.02)$ & 0.122 & 38.6 \\
\hline No & 10 & $0.85(0.70,1.00)$ & 0.10 & 58.2 \\
\hline \multicolumn{5}{|l|}{ Smoking } \\
\hline Yes & 8 & $0.90(0.70,1.09)$ & 0.005 & 65.9 \\
\hline No & 10 & $0.83(0.72,0.93)$ & 0.265 & 19.3 \\
\hline \multicolumn{5}{|l|}{ Jadad } \\
\hline 3 & 4 & $0.76(0.56,0.95)$ & 0.294 & 19.3 \\
\hline 4 & 9 & $0.99(0.86,1.12)$ & 0.207 & 26.7 \\
\hline 5 & 5 & $0.74(0.59,0.89)$ & 0.184 & 35.5 \\
\hline \multicolumn{5}{|l|}{ IF } \\
\hline$>3$ & 9 & $0.84(0.70,0.98)$ & 0.171 & 30.9 \\
\hline$<3$ & 9 & $0.87(0.72,1.03)$ & 0.007 & 62.2 \\
\hline \multicolumn{5}{|l|}{ Study type } \\
\hline Case-control & 11 & $0.89(0.76,1.02)$ & 0.021 & 52.3 \\
\hline Cohort & 7 & $0.80(0.62,0.97)$ & 0.143 & 37.5 \\
\hline \multicolumn{5}{|l|}{ Country } \\
\hline USA & 8 & $0.83(0.69,0.97)$ & 0.178 & 31.3 \\
\hline Denmark & 1 & $0.81(0.48,1.42)$ & 0 & 0 \\
\hline Australia & 2 & $0.86(0.49,1.23)$ & 0.112 & 60.4 \\
\hline Italy & 2 & $1.04(0.75,1.34)$ & 0.023 & 80.6 \\
\hline Canada & 1 & $1.07(0.64,1.79)$ & 0 & 0 \\
\hline Sweden & 1 & $0.54(0.31,0.91)$ & 0 & 0 \\
\hline Taiwan, China & 1 & $0.79(0.47,1.32)$ & 0 & 0 \\
\hline Netherlands & 1 & $0.65(0.41,1.03)$ & 0 & 0 \\
\hline \multicolumn{5}{|l|}{ Geographical region } \\
\hline Europe & 5 & $0.92(0.70,1.15)$ & 0.006 & 72.1 \\
\hline
\end{tabular}




\begin{tabular}{lllll} 
Oceania & 3 & $0.77(0.55,0.99)$ & 0.210 & 36.0 \\
America & 9 & $0.84(0.71,0.98)$ & 0.211 & 26.2 \\
Asia & 1 & $0.79(0.47,1.32)$ & 0 & 0 \\
\hline
\end{tabular}

IF, impact factor; No., Number; RR, relative risk; CI, confidence interval; USA, the United States of America; BMI, body mass index; OCP, oral contraceptive pill.

detailed meta-analysis to determine these differences due to the lack of available studies.

In conclusion, the present meta-analysis of 7 cohort and 11 case-control studies showed that tea consumption was significantly associated with a reduced risk of ovarian cancer. More population-based studies, especially highquality cohort trials, may be more effective in confirming whether tea consumption prevents ovarian cancer. Further studies in different populations with different tea types in varied dosages are required to correctly ascertain the relationship between tea consumption and the risk of ovarian cancer. Future studies on tea consumption and ovarian cancer risk should focus on the most-common ovarian cancer histotypes separately.

\section{MATERIALS AND METHODS}

\section{Literature sources and search}

A literature search was conducted using MEDICINE, Scopus, PubMed, and Web of Science databases for all relevant studies published in English-language journals
Study

ID
$\%$

ES $(95 \% \mathrm{Cl}) \quad$ Weight
Gosvig CF et al. (2015)

Braem MG et al. (2012)

Nagle CM et al. (2010)

Tworoger SS et al. (2008)

Song YJ et al. (2008)

Steevens J et al. (2007)

Silvera SA et al. (2007)

Baker JA et al. (2007)

Gates MA et al. (2007)

Larsson et al. (2005)

Jordan et al. (2004)

Goodman et al. (2003)

Yen ML et al. (2003)

Tavani et al. (2001)

Kuper et al. (2000)

Zheng et al. (1996)

La Vechia et al. (1992)

Miller et al. (1987)

Overall (I-squared $=48.4 \%, p=0.011$ )

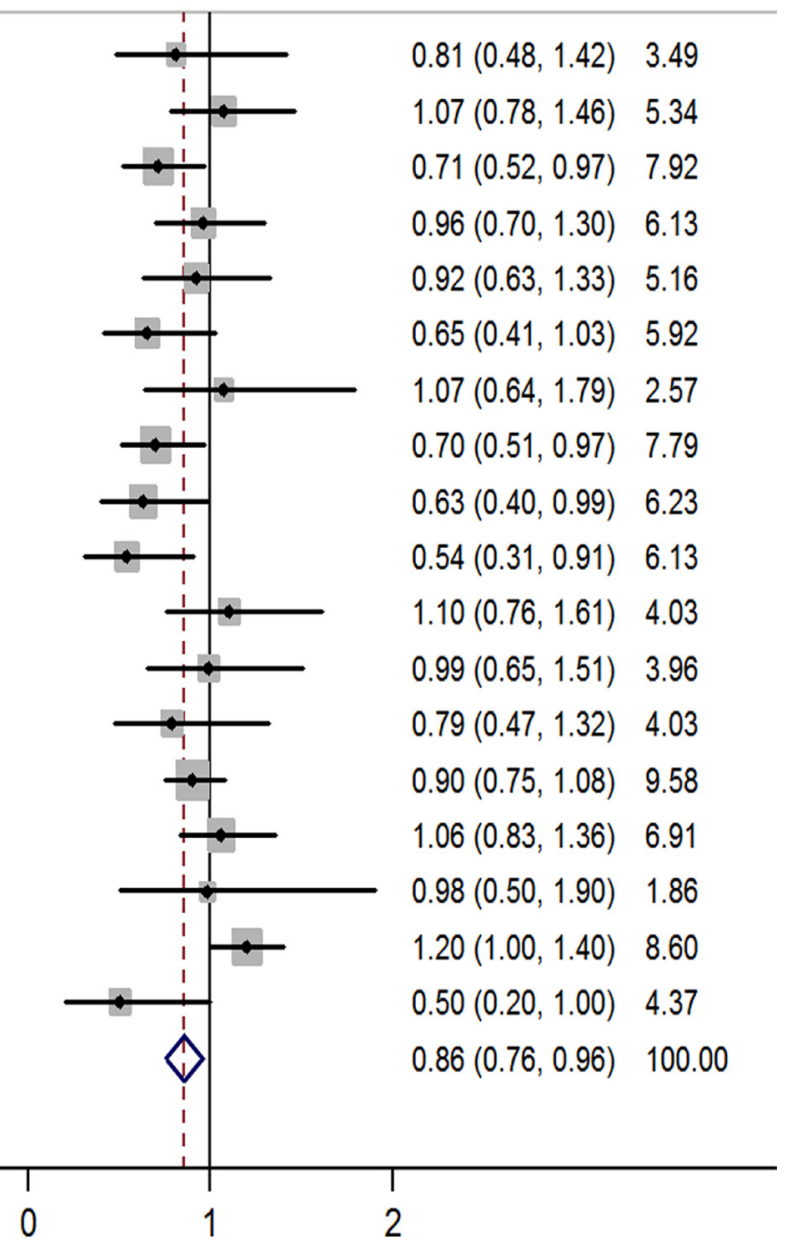

Figure 2: Forest plot of studies evaluating the association between tea consumption and risk of ovarian cancer, ES: effect size. 
Meta-analysis fixed-effects estimates (exponential form)

Study ommited

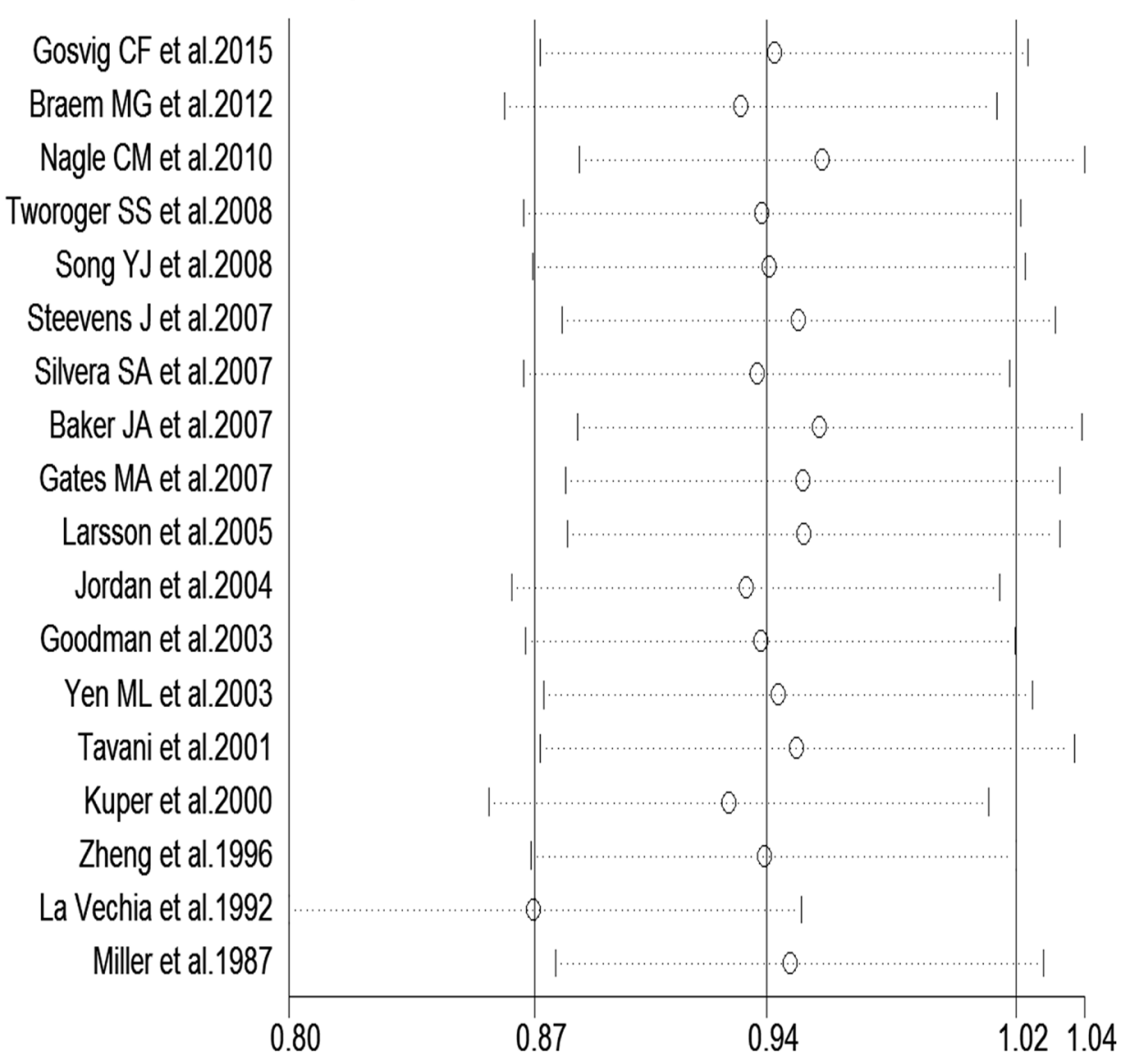

Figure 3: Sensitivity analysis of tea consumption and risk of ovarian cancer showing that omission of any study did not alter the observed effect.
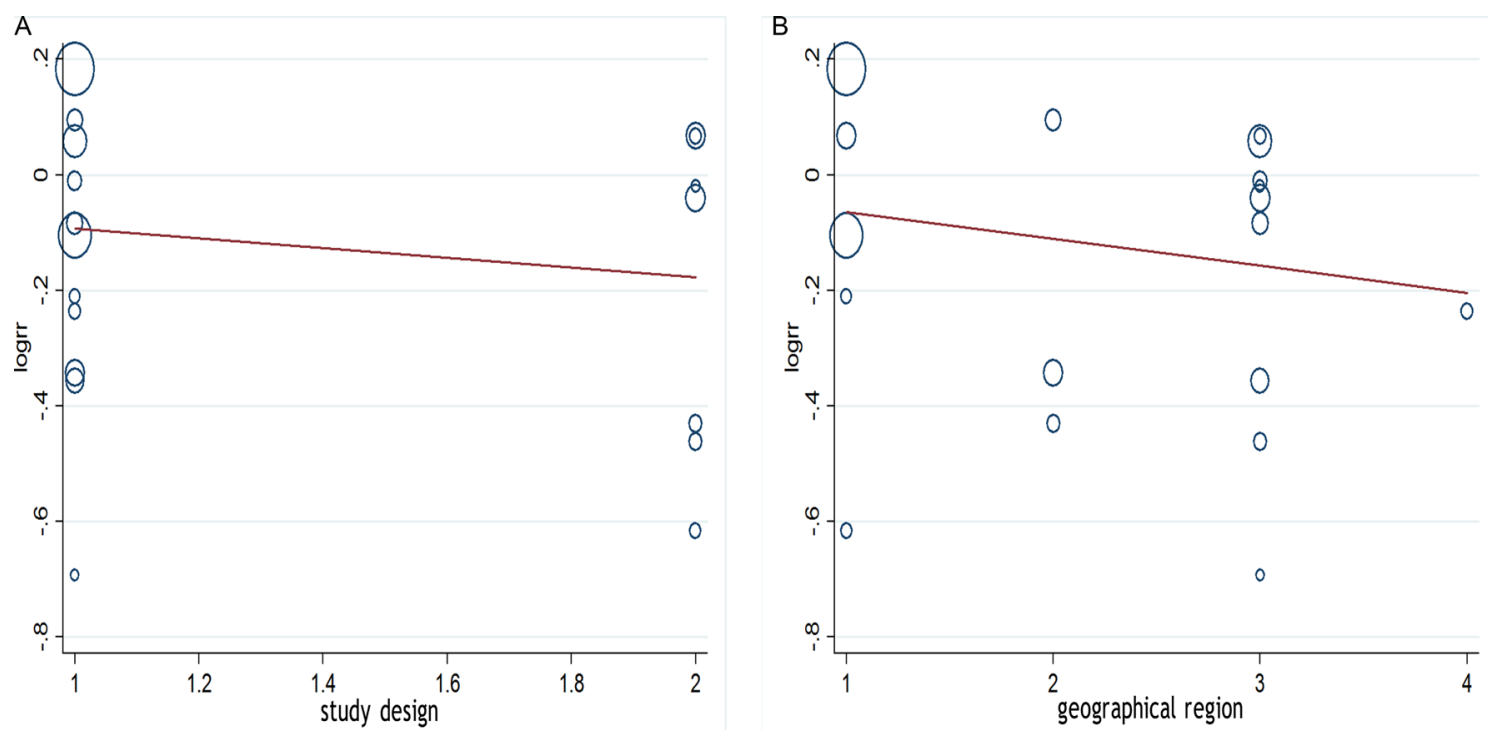

Figure 4: (A, B) Meta-regulation of study design and risk of ovarian cancer showing that study design was associated with a $47.90 \%$ heterogeneity reduction across the studies, and geographical region was associated with a $44.60 \%$ heterogeneity reduction across the studies. 


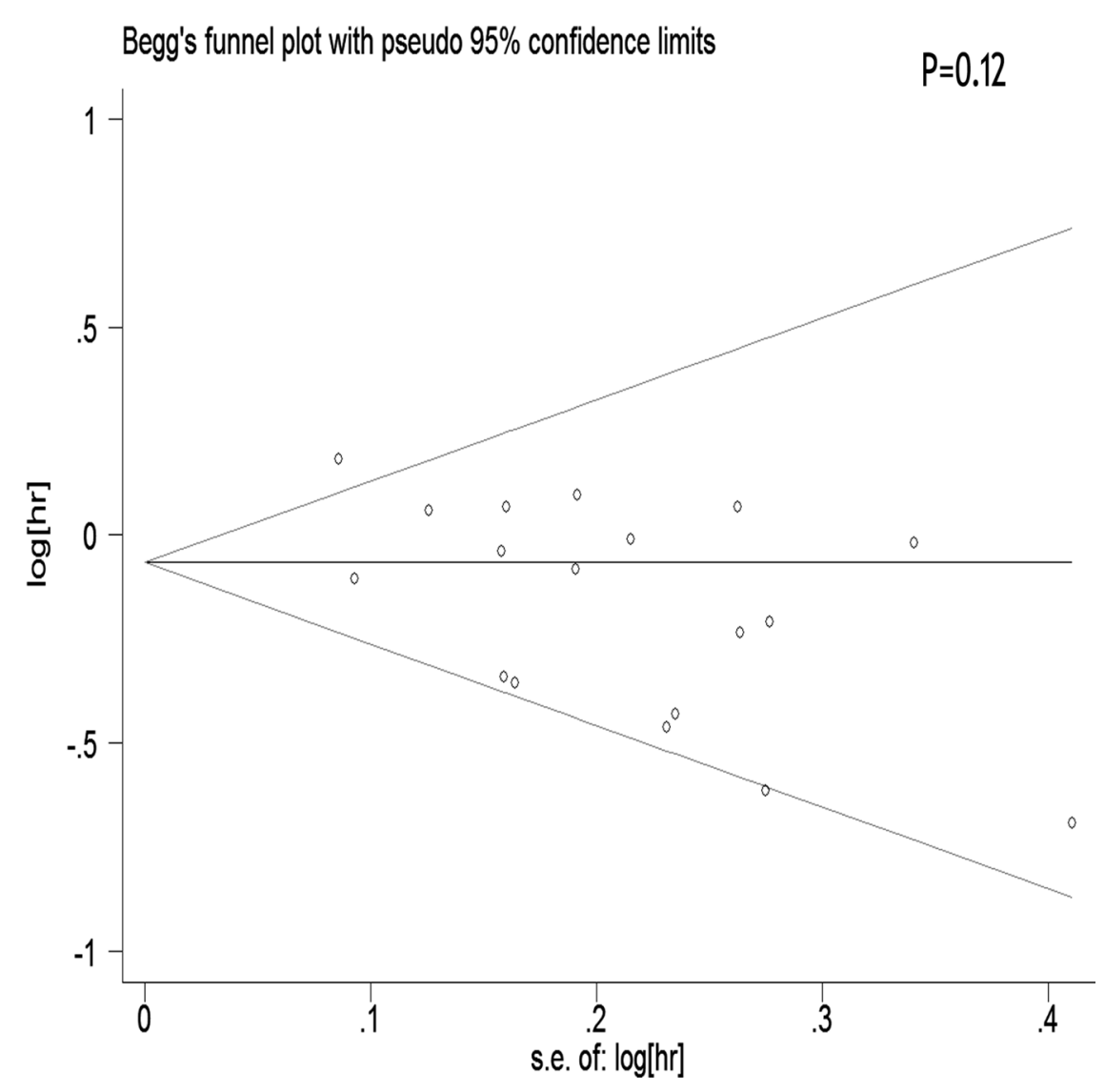

Figure 5: Begger's funnel plot assessing publication bias among the studies.

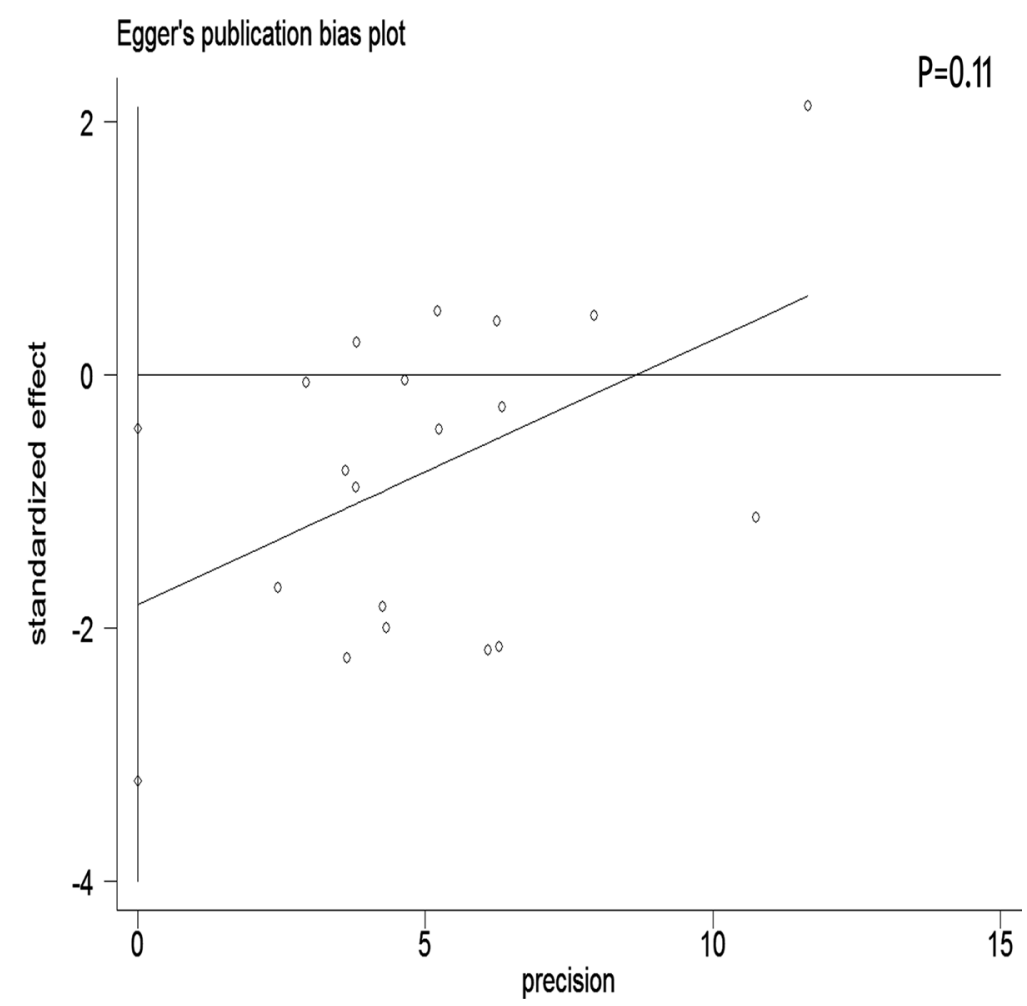

Figure 6: Egger's funnel plot assessing publication bias among the studies. 
up to April 2016. Methodology adhered to the PRISMA guidelines. The search terms included "tea" or "black tea" or "green tea" and "ovary" or "ovarian" and "malignancy" or "neoplasm" or "tumor" or "cancer." We also reviewed the list of references of each comparative study.

\section{Study selection}

Observational studies that investigated the relationship between tea consumption and ovarian cancer risk were collected independently by two authors. The inclusion criteria were as follows: (i) a case-control or prospective cohort design; (ii) investigation of the association between tea consumption and ovarian cancer incidence; (iii) availability of RR (relative risk) estimates or odds ratios or risk ratios or hazard ratio and 95\% CIs. The exclusion criteria were (i) lack of available data and (ii) the following types of articles: news, previews, reports, reviews, comments, and discussions. When there were multiple publications from the same period or in the same population, studies with publication bias were excluded from our meta-analysis. Rate ratio, risk ratio, odds ratio (OR), and hazard ratio (HR) were used as the different measures of RR in all included studies. Because the absolute risk of ovarian cancer is very low, these values were equal to the RR.

\section{Data extraction and methodological quality assessment}

Two authors independently collected the following data from each study: first author of the study, publication date, location of the population studied, study period, number of cases or subjects and study population, exposure range, study-specific adjusted ORs, RRs, or HRs with their 95\% CIs for the highest category of tea consumption versus the lowest, confounding factors for matching or adjustments, and Jadad scale from the literature. The methodological quality of the enrolled studies was assessed independently by two authors using the Jadad scale [39].

\section{Statistical analyses}

The RR's adjusted for most confounding factors were used for the association across studies. The heterogeneity was assessed using $I^{2}$ statistics. For the $\mathrm{I}^{2}$ statistic, heterogeneity was interpreted as absent ( $\mathrm{I}^{2}$ : $\left.0 \%-25 \%\right)$, low $\left(\mathrm{I}^{2}: 25.1 \%-50 \%\right)$, moderate $\left(\mathrm{I}^{2}: 50.1 \%-75 \%\right)$, or high $\left(\mathrm{I}^{2}: 75.1 \%-100 \%\right)$. Subgroup analyses were performed according to (i) adjustment for family history of cancer (yes/ no), adjustment for menopause status (yes/no), adjustment for education (yes/no), adjustment for OCP use (yes/no), adjustment for BMI (yes/no), adjustment for smoking (yes/ no); (ii) Jadad scale, impact factor, and study design; and (iii) country where the study was conducted. Pooled RR values and corresponding 95\% CIs were estimated using the random-effect model [40], which assumed that the studies included in the meta-analysis had varying effect sizes. To investigate the potential sources of betweenstudy heterogeneity, we carried out a meta-regression analysis and sensitivity analysis by excluding one study at a time to explore whether the results were significantly influenced by a specific study [41]. Publication bias was assessed using Egger's and Begg's tests [42, 43]. However, we did not evaluate a dose-response relationship between tea consumption and ovarian cancer risk due to the lack of date and the difficulty in converting from servings or other units into grams per day. Stata version 13.0 (StataCorp, College Station, TX) was used for statistical analysis. We also performed a meta-regression analysis to test the study design, geographical region.

\section{ACKNOWLEDGMENTS AND FUNDING}

We would like to thank the native English speaking scientists of Elixigen Company (Huntington Beach, California) for editing our manuscript.

\section{CONFLICTS OF INTEREST}

The authors report no conflicts of interests. We confirm that none of the authors are related to authors of studies included in the meta-analysis.

\section{REFERENCES}

1. Torre LA, Bray F, Siegel RL, Ferlay J, Lortet-Tieulent J, Jemal A. Global cancer statistics, 2012. CA Cancer J Clin. 2015; 65:87-108.

2. Collaborative Group on Epidemiological Studies of Ovarian C, Beral V, Doll R, Hermon C, Peto R, Reeves G. Ovarian cancer and oral contraceptives: collaborative reanalysis of data from 45 epidemiological studies including 23,257 women with ovarian cancer and 87,303 controls. Lancet. 2008; 371:303-314.

3. Duska LR. Early Integration of Palliative Care in the Care of Women with Advanced Epithelial Ovarian Cancer: The Time Is Now. Front Oncol. 2016; 6:83.

4. McGuire S. World Cancer Report 2014. Geneva, Switzerland: World Health Organization, International Agency for Research on Cancer, WHO Press, 2015. Adv Nutr. 2016; 7:418-419.

5. Angelo SN, Lourenco GJ, Magro DO, Nascimento H, Oliveira RA, Leal RF, Ayrizono Mde L, Fagundes JJ, Coy CS, Lima CS. Dietary risk factors for colorectal cancer in Brazil: a case control study. Nutr J. 2016; 15:20.

6. Hashibe M, Galeone C, Buys SS, Gren L, Boffetta P, Zhang ZF, La Vecchia C. Coffee, tea, caffeine intake, and the risk of cancer in the PLCO cohort. Br J Cancer. 2015; 113:809-816. 
7. Guercio BJ, Sato K, Niedzwiecki D, Ye X, Saltz LB, Mayer RJ, Mowat RB, Whittom R, Hantel A, Benson A, Atienza D, Messino M, Kindler H, et al. Coffee Intake, Recurrence, and Mortality in Stage III Colon Cancer: Results From CALGB 89803 (Alliance). J Clin Oncol. 2015; 33:3598-3607.

8. Yang CS, Wang X, Lu G, Picinich SC. Cancer prevention by tea: animal studies, molecular mechanisms and human relevance. Nat Rev Cancer. 2009; 9:429-439.

9. Chung FL, Schwartz J, Herzog CR, Yang YM. Tea and cancer prevention: studies in animals and humans. J Nutr. 2003; 133:3268S-3274S.

10. Zhang YF, Xu Q, Lu J, Wang P, Zhang HW, Zhou L, Ma XQ, Zhou YH. Tea consumption and the incidence of cancer: a systematic review and meta-analysis of prospective observational studies. Eur J Cancer Prev. 2015; 24:353-362.

11. Oppeneer SJ, Robien K. Tea consumption and epithelial ovarian cancer risk: a systematic review of observational studies. Nutr Cancer. 2011; 63:817-826.

12. Steevens J, Schouten LJ, Verhage BA, Goldbohm RA, van den Brandt PA. Tea and coffee drinking and ovarian cancer risk: results from the Netherlands Cohort Study and a metaanalysis. Br J Cancer. 2007; 97:1291-1294.

13. Braem MG, Onland-Moret NC, Schouten LJ, Tjonneland A, Hansen L, Dahm CC, Overvad K, Lukanova A, Dossus L, Floegel A, Boeing H, Clavel-Chapelon F, ChabbertBuffet $N$, et al. Coffee and tea consumption and the risk of ovarian cancer: a prospective cohort study and updated meta-analysis. Am J Clin Nutr. 2012; 95:1172-1181.

14. Gosvig CF, Kjaer SK, Blaakaer J, Hogdall E, Hogdall C, Jensen A. Coffee, tea, and caffeine consumption and risk of epithelial ovarian cancer and borderline ovarian tumors: Results from a Danish case-control study. Acta Oncol. 2015; 54:1144-1151.

15. Nagle CM, Olsen CM, Bain CJ, Whiteman DC, Green AC, Webb PM. Tea consumption and risk of ovarian cancer. Cancer Causes Control. 2010; 21:1485-1491.

16. Tworoger SS, Gertig DM, Gates MA, Hecht JL, Hankinson SE. Caffeine, alcohol, smoking, and the risk of incident epithelial ovarian cancer. Cancer. 2008; 112:1169-1177.

17. Song YJ, Kristal AR, Wicklund KG, Cushing-Haugen KL, Rossing MA. Coffee, tea, colas, and risk of epithelial ovarian cancer. Cancer Epidemiol Biomarkers Prev. 2008; 17:712-716.

18. Silvera SA, Jain M, Howe GR, Miller AB, Rohan TE. Intake of coffee and tea and risk of ovarian cancer: a prospective cohort study. Nutr Cancer. 2007; 58:22-27.

19. Gates MA, Tworoger SS, Hecht JL, De Vivo I, Rosner B, Hankinson SE. A prospective study of dietary flavonoid intake and incidence of epithelial ovarian cancer. Int $\mathrm{J}$ Cancer. 2007; 121:2225-2232.

20. Baker JA, Boakye K, McCann SE, Beehler GP, Rodabaugh KJ, Villella JA, Moysich KB. Consumption of black tea or coffee and risk of ovarian cancer. Int J Gynecol Cancer. 2007; 17:50-54.

21. Larsson SC, Wolk A. Tea consumption and ovarian cancer risk in a population-based cohort. Arch Intern Med. 2005; 165:2683-2686.

22. Jordan SJ, Purdie DM, Green AC, Webb PM. Coffee, tea and caffeine and risk of epithelial ovarian cancer. Cancer Causes Control. 2004; 15:359-365.

23. Yen ML, Yen BL, Bai CH, Lin RS. Risk factors for ovarian cancer in Taiwan: a case-control study in a low-incidence population. Gynecol Oncol. 2003; 89:318-324.

24. Goodman MT, Tung KH, McDuffie K, Wilkens LR, Donlon TA. Association of caffeine intake and CYP1A2 genotype with ovarian cancer. Nutr Cancer. 2003; 46:23-29.

25. Tavani A, Gallus S, Dal Maso L, Franceschi S, Montella M, Conti E, La Vecchia C. Coffee and alcohol intake and risk of ovarian cancer: an Italian case-control study. Nutr Cancer. 2001; 39:29-34.

26. Kuper H, Titus-Ernstoff L, Harlow BL, Cramer DW. Population based study of coffee, alcohol and tobacco use and risk of ovarian cancer. Int J Cancer. 2000; 88:313-318.

27. Zheng W, Doyle TJ, Kushi LH, Sellers TA, Hong CP, Folsom AR. Tea consumption and cancer incidence in a prospective cohort study of postmenopausal women. Am J Epidemiol. 1996; 144:175-182.

28. La Vecchia C, Negri E, Franceschi S, D'Avanzo B, Boyle P. Tea consumption and cancer risk. Nutr Cancer. 1992; 17:27-31.

29. Miller DR, Rosenberg L, Kaufman DW, Helmrich SP, Schottenfeld D, Lewis J, Stolley PD, Rosenshein N, Shapiro S. Epithelial ovarian cancer and coffee drinking. Int J Epidemiol. 1987; 16:13-17.

30. Hayakawa S, Saito K, Miyoshi N, Ohishi T, Oishi Y, Miyoshi M, Nakamura Y. Anti-Cancer Effects of Green Tea by Either Anti- or Pro- Oxidative Mechanisms. Asian Pac J Cancer Prev. 2016; 17:1649-1654.

31. Weerawatanakorn M, Lee YL, Tsai CY, Lai CS, Wan X, Ho CT, Li S, Pan MH. Protective effect of theaflavin-enriched black tea extracts against dimethylnitrosamine-induced liver fibrosis in rats. Food Funct. 2015; 6:1832-1840.

32. Li MJ, Yin YC, Wang J, Jiang YF. Green tea compounds in breast cancer prevention and treatment. World J Clin Oncol. 2014; 5:520-528.

33. Trudel D, Labbe DP, Bairati I, Fradet V, Bazinet L, Tetu B. Green tea for ovarian cancer prevention and treatment: a systematic review of the in vitro, in vivo and epidemiological studies. Gynecol Oncol. 2012; 126:491-498.

34. Beltz LA, Bayer DK, Moss AL, Simet IM. Mechanisms of cancer prevention by green and black tea polyphenols. Anticancer Agents Med Chem. 2006; 6:389-406.

35. Sun SY, Hail N Jr, Lotan R. Apoptosis as a novel target for cancer chemoprevention. J Natl Cancer Inst. 2004; 96:662672. 
36. Mandel SA, Weinreb O, Amit T, Youdim MB. Molecular mechanisms of the neuroprotective/neurorescue action of multi-target green tea polyphenols. Front Biosci (Schol Ed). 2012; 4:581-598.

37. Gao Y, Rankin GO, Tu Y, Chen YC. Inhibitory Effects of the Four Main Theaflavin Derivatives Found in Black Tea on Ovarian Cancer Cells. Anticancer Res. 2016; 36:643-651.

38. Lim DY, Shin SH, Lee MH, Malakhova M, Kurinov I, Wu Q, Xu J, Jiang Y, Dong Z, Liu K, Lee KY, Bae KB, Choi BY, et al. A natural small molecule, catechol, induces c-Myc degradation by directly targeting ERK2 in lung cancer. Oncotarget. 2016; 7:35001-35014. doi: 10.18632/ oncotarget.9223.

39. Jadad AR, Moore RA, Carroll D, Jenkinson C, Reynolds DJ, Gavaghan DJ, McQuay HJ. Assessing the quality of reports of randomized clinical trials: is blinding necessary? Control Clin Trials. 1996; 17:1-12.
40. Harrison XA. A comparison of observation-level random effect and Beta-Binomial models for modelling overdispersion in Binomial data in ecology \& evolution. PeerJ. 2015; 3:e1114.

41. Higgins JP, Thompson SG. Controlling the risk of spurious findings from meta-regression. Stat Med. 2004; 23:16631682.

42. Egger M, Davey Smith G, Schneider M, Minder C. Bias in meta-analysis detected by a simple, graphical test. BMJ. 1997; 315:629-634.

43. Begg CB, Mazumdar M. Operating characteristics of a rank correlation test for publication bias. Biometrics. 1994; 50:1088-1101. 